\title{
PENGETAHUAN IBU TENTANG NUTRISI PADA PRESCHOOL DI TK DHARMA WANITA CAMPUREJO KEDIRI (Mother knowledge preschool nutrition at TK Dharma Wanita Campurejo Kediri)
}

\author{
Diah Asriningrum \\ Akbid Medika Wiyata Kediri \\ email: diah.asri.@yahoo.com
}

\begin{abstract}
Preshool is called golden age in child growth.Called golden age because there are many importan growth in this periode. Mom Knowledge about good nutrition for preschool being importan for her to support her child optimal growh. The study purpose was to describe the knowledge of preschool mom about nutrition preshool in Campurejo Dharma Wanita Child Shool. The study used a descriptive study designe.The study population was all mom thas has 3 - 6 year of child ages. Sample taken by purposive technique with a sample of 20 mom of preschool.The result showed that 50\% responden in bad knowledge of preshcool nutrition, 30\% was in midle knoledge and $20 \%$ responden in good knowledge. To increase off mom preshool nutritio knowledg,ethe goverment can give her same information about preshcool nutrition by formal or non formas class.
\end{abstract}

Key ward: preschool, nutrition, mom

\begin{abstract}
Abstrak: Preschool di katakana masa emas dalam pertumbuhan, di sebut Golden Age, karena banyak hal penting berkembang maksimal pada tahap perkembangan ini. Pengetahuan tentang pengaturan dan penyediaan nutrisi yang baik sangat penting di pahami oleh seorang ibu untuk mensupport perkembangan anak.Penelitian ini bertujuan untuk menggambarkan pengetahuan ibu tentang nutrisi pada preschool di TK Dharma Wanita Campurejo Kediri.Desain yang di gunakan adalah descriptif. Populasi penelitian ini adalah semua ibu Preshcool di TK Dharma Wanita Campurejo yang anaknya berusia 3-6 tahun. Penentuan sampel dilakukan dengan teknik Purposif sampling terhadap 20 responden. Penelitian dilakukan pada bulan April tahun 2015. Hasil penelitian menunjukkan 50\% responden memeiliki pengetahuan kurang tentang nutrisi pada preshcool, $30 \%$ memiliki pengetahuan cukup dan $20 \%$ responden memiliki pengetahuan baik. Untuk meningkatkan pengetahuan ibu tentang nutrisi pada preschool ini diharapkan pengelola TK bekerjasama dengan dinas kesehatan maupun lembaga pendidikan untuk memvasilitasi seminar atau pendidikan kesehatan kepada ibu tentang penyediaan nutrisi pada masa preshool agar anak dapat berkembang optimal pada masa Golden age ini.
\end{abstract}

Kata Kunci: preschool, nutrisi, ibu 
Nutrisi berkaitan dengan sifat-sifat makanan yang membangun tubuh yang sehat dan yang meningkatkan kesehatan. Anak usia pra sekolah (preeshcool) adalah anak yang berumur 36 tahun.Anak usia ini menunjukkan perke,mbangan motorik,verbal dan ketrampilan sosial secara progreshif. Pada masa ini anak mulai belajar dan menggali banyak hal(Supartini 2004). Kelompok usia ini merupakan kelompok yang menunjukkan pertumbuhan badan yang pesat namun kelompok ini merupakan kelompok tersering yang menderita kekurangan gizi (Atikah,2010).

Berdasarkan hasil pengamatan peneliti pada bulan september 2014 terhadap 3 TK di kota Kediri, masih terlihat ibu ibu yang membelikan makanan anaknya di pinggir jalan seperti Batagor, Cilot dan makanan lain yang mengandung pewarna serta pemanis untuk minumanya, ada pula ibu yang membawakan bekal anaknya dengan menu yang mengandung pengawet dan makanan botol yang juga mengandung pengawet, namun ada juga ibu yang membawakan anaknya bekal untuk makan anaknya di sekolah yang komposisinya cukup baik dan mempunyai nilai gizi, dengan cara masak yang benar. Pemberian nutrisi yang tidak benar secara kualitas maupun kuantitas dapat mempengaruhi setatus gizi npada anak, sehingga anak akan menderita kurang gizi.Hasil Riset Kesehatan Dasar (Riskesdas) menunjukkan prevalensi gizi kurang tidak mengalami perubahan dari tahun 2007 sampai tahun 2010, yaitu tetap 13,0\%.

Gizi kurang tersebut dipengaruhi berbagai macam keadaan diantaranya yaitu keadaan ekonomi, fisiologi, sosial, politik dan budaya. Salah satu penyebab yang secara langsung dapat mempengaruhi kekurangan gizi adalah makanan dan penyakit. Faktor-faktor tersebut berkaitan dengan tingkat pengetahuan, pendidikan dan keterampilan ibu. Makin rendah tingkat pengetahuan, pendidikan dan keterampilan ibu makin rendah pola nutrisi yang diberikan, begitu pula sebaliknya sehingga anak menjadi kurang gizi mengakibatkan gangguan pertumbuhan dan perkembangan pada anak usia 3-6 tahun. Gangguan ini akan menjadi serius bila tidak ditangani secara intensif (Masfathin, 2006).

Upaya menanggulangi masalah gizi kurang pada preeshooladalah ibu memberikan hidangan sehari-hari dengan susunan zat gizi yang seimbang seperti nutrisi yang beraneka ragam makanan yang dapat mencukupi kebutuhan gizi anak usia 3-6 tahun yaitu kebutuhan lengkap akan karbohidrat, lemak, protein, vitamin dan mineral. Biasakan anak sarapan atau makan pagi karena sangat penting untuk menunjang aktivitas sehari-hari dan meningkatkan konsentrasi belajar sehingga lebih mudah untuk menerima pelajaran (Pitoyo, 2008). Berdasarkan latar belakang diatas perlu dilakukan kajian secara ilmiah melalui penelitian: “ Pengetahuan Ibu Tentang Pemberian Nutrisi Pada Preeshcool di TK Dharma Wanita Campurejo Kediri.

\section{BAHAN DAN METODE}

Penelitian ini menggunakan desain descriptif, yaitu dengan mendeskripsikan atau menggambarkan fakta fakta secara sistematis dan akurat dari hasil penelitian. Populasi penelitian ini adalah semua ibu Preshcooldi TK Dharma Wanita Campurejo yang anaknya berusia 3-6 tahun.Penentuan sampel dilakukan dengan teknik Purposif sampling terhadap 20 responden yang memenuhi krioteria inklusi, ibu bersedia menjadi responden, dan berada di TK Dharma Wanita Campurejo saat pengisian lembar questioner.Variabel dalam penelitian ini adalah Pengetahuan ibu tentang nutrisai pada preschool.Instrumen yang di gunakan untuk mengumpulkan data adalah lembar Questioner .

Proses pengumpulan data dilaksanakan bulan April tahun 2015. Sebelum penelitian ini di mulai, peneliti memilih anak yang berusia 3-6 tahun, kemudian memilih anak yang ke sekolah diantar oleh ibunya, kemudian ibu di beri penjelasan dan diminta mengisi lembar persetujuan menjadi responden sebelum mengisi questioner. Setelah lembar questioner di isi oleh responde, dilakukan analisa data dengan menjumlahkan jawaban dari responden. Jawaban yang benar di beri nilai 1 dan yang salah di beri nilai 0..kemudian di prosentase dan disajikan dalam bentuk diagram gambar pada data umum dan dengan tabel distribusi frequensi ada data khusus.

\section{HASIL PENELITIAN \\ Data Umum}

Data ini meliputi karakteristik subyek penelitian berdasarkan usia, pendidikan dan pekerjaan. 
Gambar 1.Karakteristik responden berdasarkan usia

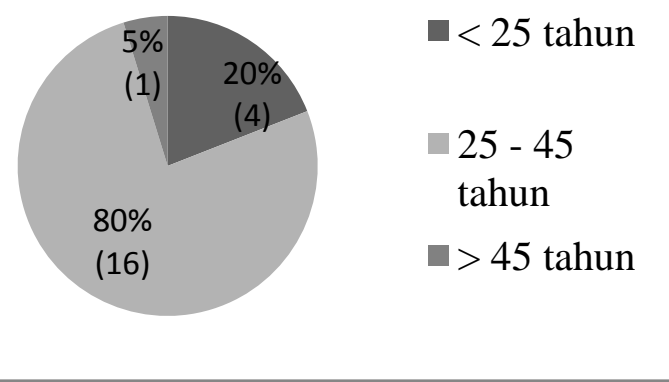

Gambar 2. Karakteristik responden berdasarkan pendidikan

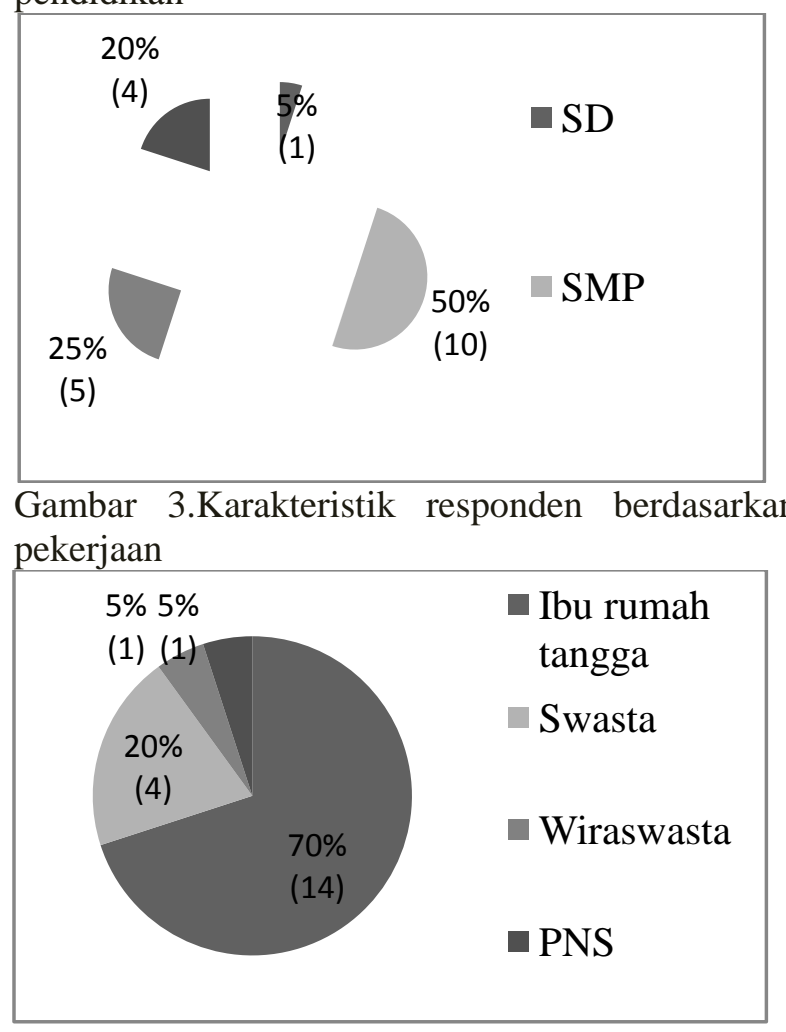

\section{Data Khusus}

Tabel 1. Distribusi frekuensi tingkat pengetahuan responden tentang pemberian nutrisi pada prescool di TK Dharma Wanita Campurejo tahun 2015

\begin{tabular}{clcc}
\hline No & Kriteria & Frekuensi & $\begin{array}{c}\text { Persentase } \\
(\mathbf{\%})\end{array}$ \\
\hline 1 & Baik & 4 & 20 \\
2 & Cukup & 6 & 30 \\
3 & Kurang & 10 & 50 \\
\hline
\end{tabular}

Keterkaitan Data Umum dengan Data Khusus

Tabel 2.Tabulasi silang usia dengan pengetahuanresponden tentang pemberian nutrisi padaprescool di TK Dharma Wanita Campurejo tahun 2015

\begin{tabular}{lcccccccc}
\hline \multirow{3}{*}{ Usia } & \multicolumn{9}{c}{ Pengetahuan } & \multicolumn{2}{c}{ Total } \\
\cline { 2 - 7 } & \multicolumn{2}{c}{ Baik } & \multicolumn{2}{c}{ Cukup } & \multicolumn{2}{c}{ Kurang } & \multicolumn{2}{c}{ Tot } \\
\cline { 2 - 7 } & $\sum$ & $\%$ & $\sum$ & $\%$ & $\sum$ & $\%$ & $\sum$ & $\%$ \\
\hline$<25 \mathrm{Th}$ & 0 & $0 \%$ & 1 & $5 \%$ & 3 & $15 \%$ & 4 & $20 \%$ \\
$25-45 \mathrm{Th}$ & 3 & $15 \%$ & 5 & $25 \%$ & 7 & $35 \%$ & 15 & $75 \%$ \\
$>45 \mathrm{Th}$ & 1 & $5 \%$ & 0 & $0 \%$ & 0 & $0 \%$ & 1 & $5 \%$ \\
\hline
\end{tabular}

Tabel 3 Tabulasi silang pendidikan dengan pengetahuan responden tentang pemberian nutrisi pada prescool di TK Dharma Wanita Campurejo tahun 2015

\begin{tabular}{|c|c|c|c|c|c|c|c|c|}
\hline \multirow{3}{*}{$\begin{array}{l}\text { Pendidi } \\
\text { kan }\end{array}$} & \multicolumn{6}{|c|}{ Pengetahuan } & \multirow{2}{*}{\multicolumn{2}{|c|}{ Total }} \\
\hline & \multicolumn{2}{|c|}{ Baik } & \multicolumn{2}{|c|}{ Cukup } & \multicolumn{2}{|c|}{ Kurang } & & \\
\hline & $\sum$ & $\%$ & $\sum$ & $\%$ & $\sum$ & $\%$ & $\sum$ & $\%$ \\
\hline SD & 0 & $0 \%$ & 0 & $0 \%$ & 1 & $5 \%$ & 1 & $5 \%$ \\
\hline SMP & 0 & $0 \%$ & 4 & $20 \%$ & 6 & $30 \%$ & 10 & $50 \%$ \\
\hline SMA & 2 & $10 \%$ & 1 & $5 \%$ & 2 & $10 \%$ & 5 & $25 \%$ \\
\hline PT & 2 & $10 \%$ & 1 & $5 \%$ & 1 & $5 \%$ & 4 & $20 \%$ \\
\hline
\end{tabular}

Tabel 4. Tabulasi silang pekerjaan dengan pengetahuan tentang pemberian nutrisi pada prescool di TK Dharma Wanita Campurejo tahun 2015

\begin{tabular}{lcccccccc}
\hline \multirow{2}{*}{ Pekerjaan } & \multicolumn{9}{c}{ Pengetahuan } & \multicolumn{2}{c}{ Total } \\
\cline { 2 - 7 } & \multicolumn{3}{c}{ Baik } & \multicolumn{2}{c}{ Cukup } & \multicolumn{2}{c}{ Kurang } & \multicolumn{2}{c}{ Tot } \\
\cline { 2 - 7 } & $\sum$ & $\%$ & $\sum$ & $\%$ & $\sum$ & $\%$ & $\sum$ & $\%$ \\
\hline Ibu RT & 2 & $10 \%$ & 5 & $25 \%$ & 7 & $35 \%$ & 14 & $70 \%$ \\
Swasta & 1 & $5 \%$ & 1 & $5 \%$ & 2 & $10 \%$ & 4 & $20 \%$ \\
Wiraswasta & 0 & $0 \%$ & 0 & $0 \%$ & 1 & $5 \%$ & 1 & $5 \%$ \\
PNS & 1 & $5 \%$ & 0 & $0 \%$ & 0 & $0 \%$ & 1 & $5 \%$
\end{tabular}

\section{PEMBAHASAN}

Preschooldi katakana masa emas dalam pertumbuhan, di sebut Golden Age, karena banyak hal baru dapat berkembang maksimal pada masa ini. Pengaturan dan penyediaan nutrisi yang baik sangat penting di pahami oleh seorang ibu untuk mensupport perkembangan anak.

Berdasarkan tabel 1. hasil penelitian pada 20 responden, didapatkan sebagian besar ibu memiliki pengetahuan kurang tentang nutrisi pada preschool yaitu 10 orang (50\%), sedangkan Ibu yang memiliki pengetahuan baik ada 4 orang (20\%), dan yang memiliki pengetahuan cukup 6 orang $(30 \%)$.

Ibu yang memiliki pengetahuan kurang tersebut $25 \%$ nya berpendidikan SD dan 50\% berpendidikan SMP. Sedangkan Ibu yang memiliki pengetahuan baik separuhnya berpendidikan SMA dan separuhnya lagi berpendidikan perguruan 
tinggi. Ini membuktikan bahwa tingginya pendidikan seseorang berhubungan dengan pengetahuan yang dimiliki, dimana semakin tinggi pendidikan semakin tinggi pula pengetahuanya.

Sesuai dengan pernyataan Notoatmojo (2007) bahwa pengetahuan merupakan hasil dari tahu, dan ini terjadi setelah orang melakukan penginderaan terhadap suatu objek tertentu. Penginderaan terjadi melalui panca indera manusia, yaitu indera penglihatan, pendengaran, penciuman, rasa dan raba. Sebagian besar pengetahuan manusia diperoleh melalui mata dan telinga. Begitu juga menurut Machfoedz (2008) bahwa implikasinya semakin tinggi tingkat pendidikan, hidup manusia akan semakin berkualitas, dimana semakin tinggi pendidikan maka seseorang akan semakin mudah untuk menerima hal-hal yang baru dan mudah menyesuaikan diri dengan hal-hal baru tersebut, tetapi tidak menutup kemungkinan bahwa pendidikan rendah punya pengetahuan dan sikap yang lebih baik. Sedangkan menurut Masfathin (2006) bahwa makin rendah tingkat pengetahuan, pendidikan dan ketrampilan ibu makin rendah pola nutrisi yang diberikan, begitu pula sebaliknya.

Kurangnya pengetahuan ibu tentang nutrisi pada Preschool dapat berdampak anak menjadi rentan terhadap berbagai penyakit, kurang maksimalnya pertumbuhan dan perkembangan anak secara fisik, dan intelektual pada emas, sehingga untuk mensukseskan program pemerintah dalam mencerdaskan kehidupan bangsa dan menciptakan bangsa yang benar benar cerdas, diperlukan sosialissi terhadap ibu tentang nutrisi pada Preschool melalui seminar maupun pendidikan yang difasilitasi oleh pihak pengelola TK secara mandiri maupun bekerjasama dengan dinas kesehatan atau sekolah kesehatan.

\section{SIMPULAN DAN SARAN Simpulan}

Dari hasil penelitian didapatkan sebagian besar ibu memiliki pengetahuan kurang tentang nutrisi pada preschool yaitu 10 orang (50\%), sedangkan Ibu yang memiliki pengetahuan baik ada 4 orang $(20 \%)$, dan yang memiliki pengetahuan cukup 6 orang $(30 \%)$.

\section{Saran}

Diperlukan sosialissi terhadap ibu tentang nutrisi pada Preschool melalui seminar maupun pendidikan yang difasilitasi oleh pihak pengelola TK secara mandiri maupun bekerjasama dengan dinas kesehatan atau sekolah kesehatan. Di harapkan ibu mengakses ilmu pengetahuan tentang nutrisi pada anaknya melalui media cetak, media elektronik maupun internet agar benar benar dapat mensupport pertumbuhan dan perkembangan anak melalui nutrisi yang di sediakanya. Diharapkan pihak sekolah melakukan deteksi tumbuh kembang secara berkala terhadap anak didiknya untuk memantau tumbuh kembang anak dan melakukan stimulasi yang tepat selain mengoptimalkan penyediaan nutrisi guna tumbuh kembang yang sempurna pada masa Golden Age.

\section{DAFTAR RUJUKAN}

Arikunto. S. 2006. Prosedur Penelitian Suatu Pendekatan Praktek. Jakarta: Rineka Cipta.

Adalila. S. 2010. Pentingnya Pendidikan Anak Usia Dini. http : // sadidadalila. Wordpress. Com. ( Diakses pada 2 januari 2014).

Almatsier. S. 2009. Prinsip Dasar Ilmu Gizi. Jakarta: Gramedia Pustaka Utama.

Aspi. J. 2010. Pendidikan Anak Usia Dini di Indonesia dan Target Capaian PAUD. http: // www. tunasbangsaku- tk /. (Diakses 9 Mei 2011).

Departemen Kesehatan Republik Indonesia. 2005. Standar Pemantauan Pertumbuhan Balita. Direktorat Jenderal Bina Kesehatan Masyarakat, Direktorat Gizi Masyarakat.

Effendy. 2004. Dasar-dasar Keperawatan Kesehatan Masyarakat. Jakarta. EGC.

Hasan. M. 2009. Pendidikan Anak Usia Dini (PAUD). Diva press. Yogyakarta.

Hidayat, Azis Alimul. 2012. Metode Penelitian Kebidanan Teknik AnalisisData. Jakarta: Salemba Medika.

Ircham Machfoedz MS. 2008. Metodologi Penelitian. Fitramaya.Yogyakarta.

Lian, C.W., et. Al. (2007). A Qualitative study on Malnutrition in Children from the perspectives of Health Workers in Tumpat, Kelantan. Mal J Nutr 13 (1) : 19-28, 2007.

Masfathin. (2006). Kisah Sedih Negara Yang Seharusnya Kucinta. (Online) (http://www.masfathin.multiply.com, diakses 25 Juni 2008). 
Notoadmodjo, S. 2007. Konsep perilaku dan perilaku kesehatan. Dalam: Promosi Kesehatan dan Ilmu Perilaku. Rineka Cipta, Jakarta: 133-151.

Notoatmodjo, Soekidjo. 2010. Metodologi Penelitian Kesehatan. Jakarta: Rineka Cipta.

Nursalam. 2003. Konsep dan Penerapan Metodologi Penelitian Ilmu Keperawatan . Jakarta: salemba Medika.

Notoatmodjo, Soekidjo. 2005. Metodologi Penelitian Kesehatan. Jakarta: Rineka Cipta.

Pitoyo.(2008).Tips Praktis Mengatasi Anak Susah Makan. (http://www.Pitoyo.com, diakses 25 Januari 2008).

Proverawati, Atikah. 2010. Gizi Untuk Kebidanan. Yogyakarta : Nuha Medika.

Poerwodarminto. 2003. Kamus Bahasa Indonesia. Jakarta: Balai Pustaka.

(RISKESDAS) Riset Kesehatan Dasar. 2010. Laporan Nasional Riset Kesehatan Dasar. Jakarta. Badan Penelitian dan Pengembangan Kesehatan Departemen Kesehatan Republik Indonesia.

Soekirman. (2008). Gizi Buruk, Kemiskinan, dan $K K N$. Diperoleh dari www.pdrc.co.id. (Diambil tanggal 16 Februari 2009).

Soekanto, 2002.Sosial Budaya Dasar. Jakarta: Gravindo Persaja.

Sulistyoningsih. 2011. Gizi Untuk Kesehatan Ibu dan Anak. Jogjakarta. Graha Ilmu. http: // dr. Suparyanto. Blogspot. Com / 2012/ 02/ Konsep- Dasar- Menu- Seimbang.html. (Diakses 20 Februari 2012).

Sudiarti. (2007). Departemen Gizi dan Kesehatan Masyarakat FKM UI.

Siswono. (2006). Program Untuk Balita Kurang Gizi. Diperoleh dari www. republika. co. id. (Diakses 23 Februari 2009).

Sugiyono. 2004. Metode Penelitian Kuantitatif Kualitatif dan $R \& D$. Bandung : Alfabeta : 87.

Tiran, Denise. 2005. Kamus Saku Bidan. Edisi 10. Jakarta: EGC. 